\title{
Effect of dietary components on miRNA and colorectal carcinogenesis
}

\author{
Adewale Oluwaseun Fadaka1 ${ }^{1,}$ D , Babajide A. Ojo², Olusola Bolaji Adewale, Temitope Esho ${ }^{4}$ \\ and Ashley Pretorius ${ }^{5}$
}

\begin{abstract}
Background: Colorectal cancer (CRC) is one of the most common cancers diagnosed and among the commonest causes of cancer-related mortality globally. Despite the various available treatment options, millions of people still suffer from this illness and most of these treatment options have several limitations. Therefore, a less expensive, noninvasive or a treatment that requires the use of dietary products remains a focal point in this review.

Main body: Aberrant microRNA expression has been revealed to have a functional role in the initiation and progression of CRC. These has shown significant promise in the diagnosis and prognosis of CRC, owing to their unique expression profile associated with cancer types and malignancies. Moreover, microRNA therapeutics show a great promise in preclinical studies, and these encourage further development of their clinical use in CRC patients. Additionally, emerging studies show the chemo-preventive potential of dietary components in microRNA modulation using several CRC models. This review examines the dietary interplay between microRNAs and CRC incidence. Improving the understanding of the interactions between microRNAs and dietary components in the carcinogenesis of CRC will assist the study of CRC progression and finally, in developing personalized approaches for cancer prevention and therapy.
\end{abstract}

Conclusion: Although miRNA research is still at its infancy, it could serve as a promising predictive biomarkers and therapeutic targets for CRC. Given the ever-expanding number of miRNAs, understanding their functional aspects represents a promising option for further research.

Keywords: Colorectal cancer, microRNA, Biomarkers, Diet, Chemoprevention

\section{Background}

Colorectal cancer is the third most commonly diagnosed cancer and the fourth leading cause of cancer-related deaths in the world [1]. It is the fourth most common cancer in South Africa in both male and female and the 6th most lethal of all known cancers [2]. Bray et al. [3] has predicted that there will be an increase in all CRC incidence cases from over 12 million in 2008 to about 22.2 million by 2030 [4]. About 24 million new cases of CRC was expected to be diagnosed by 2050 , out of which $70 \%$ of these cases would be found in the developing countries [5]. Occurrence of this disease is greater in America and

\footnotetext{
*Correspondence: silvernonferous@gmail.com; 3782900@myuwc.ac.za

${ }^{1}$ Department of Biotechnology, Faculty of Natural Sciences, University

of the Western Cape, Cape Town, South Africa

Full list of author information is available at the end of the article
}

Europe when compared to low and middle-income countries. However, there is still high burden of this disease due to lack of early diagnosis of CRC as a result of limited resources in these low and medium-income countries, such as most African countries. Although, this is avoidable because CRC is one of the cancers that is almost $100 \%$ preventable [6], but most of the world's population still lack information of this disease as well as its relationship with diet.

Treatment options for CRC is largely dependent on the stage of the tumor, that is, how far it has metastasized. A common non-invasive screening test currently employed is the Fecal Occult Blood Test (FOBT), but the test presents poor sensitivity and specificity [7]. Other screening tests such as the Fecal Immunochemical Test (FIT), the fecal DNA test and the plasma SEPT-9 gene 
methylation test [8], as well as colonoscopy [9] are in use. Some clinicians use the FOBT and colonoscopy together or at different times [10]. Serum biomarker test such as carcinoembryonic antigen (CEA), carbohydrate antigens (CA) 19-9, and CA 125 used for CRC diagnosis are also non-specific [11]. To date, colonoscopy is the most commonly used test in the detection of CRC, which has been found to reduce the risk of CRC by $30-75 \%$, but the limitation to this technique is its high cost and invasiveness [12], which makes it ineffective in resource-limited settings. Chemotherapeutic agents that often used in post-surgery lack tissue selectivity. At early stage, CRC may not show obvious signs or symptoms such as colon and/or rectal bleeding, belly pain, change in bowel habit (diarrhea), constipation, stool narrowing, and sudden weight loss. This disease can be asymptomatic until latter stages when the cancer has metastasized [13]. Globally, the major challenge to CRC treatment is early detection, which makes the current treatment options to be administered so late, typically after the cancer has metastasized. If the cancer is detected early, and polyps are removed by surgery, this will reduce both the incidence and mortality cases of CRC. To achieve this, more non-invasive, selective and specific diagnostic tools which can detect the tumour at an early need to be reviewed.

Non-coding RNAs, most especially miRNAs, are attracting considerable interest, with increasing evidences on the role of miRNAs' expression in CRC development and progression [14]. This has led to the use of miRNAs as therapeutic targets. Nevertheless, the mechanism through which a single miRNA controls gene networks by and the possible in vivo adverse effects of the miRNA and/or anti-miRNA are yet to be fully explored. As earlier mentioned, early CRC detection tools are faced with several challenges, thereby limiting the development of a standardized biochemical diagnostic approaches which are non-invasive, more sensitive and specific for CRC stages. Several factors have been linked to the disease risk factors but adopting a healthy lifestyle could be a preventable means. As a result of these, diet has been implicated in a crucial role in preventing CRC [15]. Therefore, diet-miRNA interplay and identification of the miRNAs that are expressed in CRC would be a focal point in this review.

\section{Colorectal cancer}

Colorectal cancer is the occurrence of abnormal growth in the colon or rectum. It is the fourth most common cause of cancer-related deaths and one of the most ranked type of cancer worldwide [16]. It is the second and third most common cancer in women and men, respectively, and also accounted for about $10 \%$ of the total cancer cases worldwide [16]. The cancer begins with an abnormal growth of the cells lining the colon and rectum. These cells divide uncontrollably and rapidly thereby leading to the formation of a non-cancerous growth or benign tumour known as a polyp. The polyp grows gradually and over a period of 10-20 years (Fig. 1) [17]. An adenomatous polyp or adenoma is the most common type, and about one-third to one-half of all individuals will eventually develop one or more adenomas [18]. Although not all polyps give rise to CRC, but CRC is almost always developed from a polyp and all adenomas have the possibility to be cancerous [18]. The possibility that an adenoma will become cancerous increases as it becomes bigger [19]. Cancer arising from the inner lining of the colorectum is called adenocarcinoma, and accounts for approximately $96 \%$ of all CRCs [20]. Series of DNA changes in a polyp's cell result in its the development into malignant tumor over a period of time (Fig. 1). Initially, these cancer cells are confined to the surface of a polyp, but can grow into the wall of the colon or rectum, which eventually spreads to lymph nodes and other organs, such as the liver or lungs [21].

\section{CRC pathogenesis and miRNA involvement}

The molecular mechanism of colorectal carcinogenesis is a multistep process involving genetic, epigenetic and aberrant immunologic pathway as a major contributor of colorectal carcinogenesis [22-24]. miRNAs are often dysregulated in tumors either by genetic or epigenetic factors, and are currently being investigated for their potential as biomarkers in cancer diagnostics (Fig. 2) [25]. This non-coding RNA has been implicated in the mechanism by which gene expression of various cancerassociated genes are controlled and their expression may be altered in the process. A series of studies have highlighted the role of miRNAs in the development of this disease. CRC-related miRNAs have been demonstrated to regulate the genes by various mechanisms, including epigenetic modifications, long non-coding RNAmiRNA, and long non-coding RNA-protein interactions, and by their actions as miRNA precursors. Since miRNAs can be detected in human body fluid and have good specificity and accessibility, they have been suggested to be used as novel potential biomarkers for CRC diagnosis and prognosis as well as in the prediction of the response to therapy [26]. miRNAs have been implicated in a number of events, such as epigenetic, transcriptional, and post-transcriptional regulation [27]. These non-coding RNAs exhibit unique profiles in various human cancers such as colorectal cancer, reflecting disease progression [28]. Studies have previously reported the involvement of miRNAs in cancer initiation and progression but recently, their roles as drivers of tumor suppressor and oncogenic function have been evaluated in several cancer types [29]. 


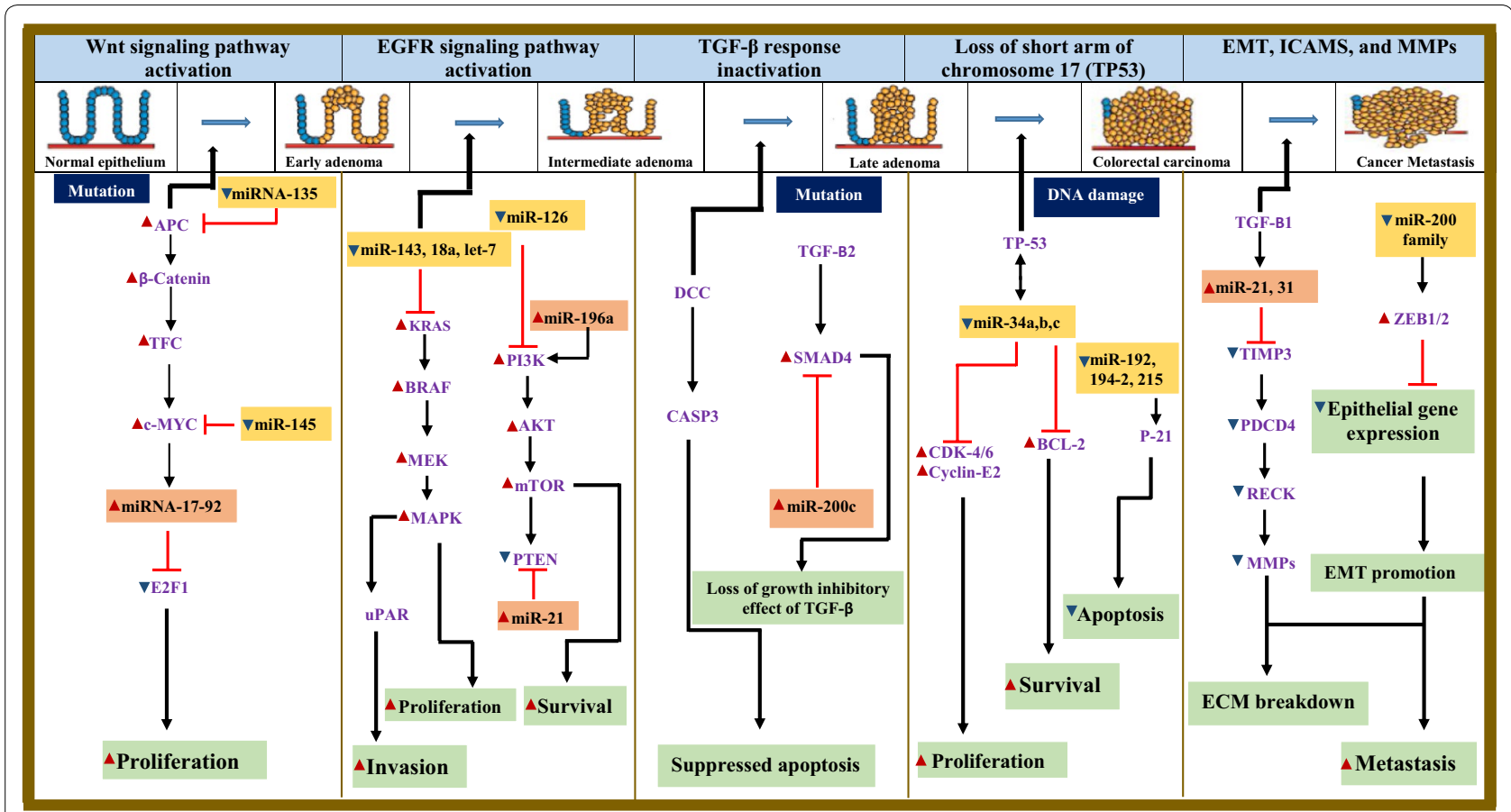

Fig. 1 microRNAs and genetic/epigenetic alterations involved in adenoma-carcinoma sequence. Red arrows_up-regulation; blue arrowsdownregulation. Experimentally validated miRNAs are shown alongside with their target genes in altered expression in CRC

Several studies have also shown the association of noncoding RNAs in colorectal carcinogenesis through the stimulation or inhibition of apoptosis, cell proliferation, differentiation, invasion and metastasis [30-35].

\section{Genetic regulation of colorectal carcinogenesis}

Genetic instability has been considered fundamental to the multistep process of tumor growth and metastatic progression for decades [36]. A wide range of genetic mutations is found in most cancer subtypes (Fig. 2). The most common gene mutation in CRC is the APC gene from the normal epithelium followed by the K-ras, DCC and p53 genes leading to sporadic carcinoma [37]. DNA hypermethylation of tumor suppressor gene promoter regions has been intensively studied to demonstrate its critical role in gene silencing (Fig. 2). Histone modification includes histone methylation and deacetylation, both of which have been shown to be associated with DNA methylation [22].

\section{Epigenetic modifications and miRNA in CRC}

Epigenetic alterations have the ability to deregulate the expression of any type of transcript. However, the exact mechanisms of epigenetic regulation of non-coding
RNAs are still unclear although, these RNAs are subject to the same epigenetic regulatory mechanisms as protein-coding genes. Several studies have reported the regulatory mechanism of miRNA to clarify the network that underlie the aberrant expression in tumor metastasis. Furthermore, aberrant epigenetic regulation affects abnormal miRNA expression in cancers. miR21, miR-106, and miR-144 were reportedly upregulated in patients samples with CRC compared with normal individuals [38]. miR 143 and miR-145 were significantly downregulated in colorectal adenoma compared to normal colon sample [39]. These miRNAs were further confirmed to be significantly reduced in colorectal neoplasia and act as tumor suppressor miRNAs in the colorectum [40-44]. Zhang et al. [45] also revealed the induction of apoptosis through BCL-2 inhibition by miR-148a upregulation in CRC while the downregulation was linked to increased tumor size [46]. Attenuated miR-34a and miR-200c expression are associated with metastasis in CRC [47, 48]. Lujambio et al. [49] identified cancer-specific $\mathrm{CpG}$ island hypermethylation of the promoter lesion with the transcription of miR-148a, miR-34b/c, and miR-9. miR-34a also have effect on colorectal cancer invasion and metastasis in conjunction with IL-6R, ZNF281, MET, snail family zinc finger 1 and 2 (SNAI1, SNAI2) and $\beta$-catenin (CTNNB1) [47, 50-52]. 


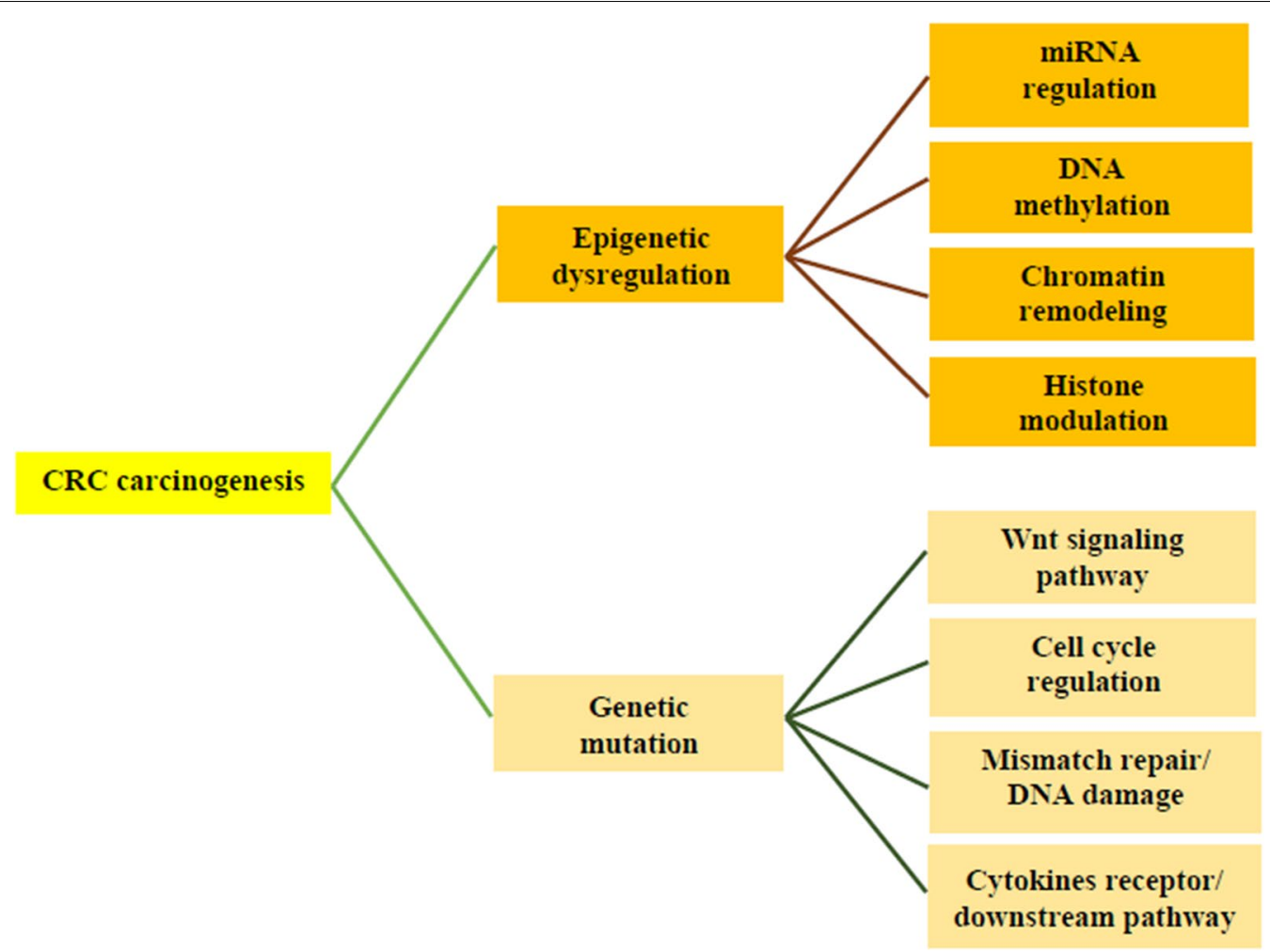

Fig. 2 Genetic and epigenetic mechanisms of colorectal carcinogenesis. Mutation of genes involved in the Wnt signaling pathway plays a superior role in colorectal carcinogenesis. Genes that are related to cell cycle progression. DNA repair, and cytokine signaling have also been shown to be pivotal in colorectal carcinogen. DNA hypermethylation of tumor suppressor gene promoter regions has been intensively studied to demonstrate its critical role in gene silencing. Histone modification includes histone methylation and deacetylation, both of which have been shown to be associated with DNA methylation

\section{Overview of miRNA}

Micro RNAs are short single stranded non-coding RNAs, consisting of about $19-25$ nucleotides. They are responsible for the regulation of translation of genes by binding to the $3^{\prime}$-untranslated region of target mRNAs through sequence-specific manner. These miRNAs reportedly play vital roles in inflammation and carcinogenesis, which can be linked to their oncogenic or tumor suppressive properties [53]. Alterations in miRNA expression are implicated in different human cancers, which include breast cancer, CRC, liver cancer and lung cancer [54]. For gene silencing, cells can use miRNA, which binds and represses messenger RNA (mRNA), thereby turning off genes that are not required in translating genetic information into proteins. This miRNA participates in the regulatory mechanisms of cell's development through death, and the dysregulation can be implicated in several diseases such as cancer and heart diseases [55].

miRNAs have been recognized as potential biomarkers for early detection, as well as prognostic and therapeutic approach for CRC because of their high level of specificity and selectivity.

\section{Synthesis of miRNA}

As earlier mentioned, miRNA is an important class of post-transcriptional regulators of about 22 nucleotides in length [56], and it carries out its biological functions by binding to the $3^{\prime}$ untranslated regions (UTRs) of its target messenger RNA/s (mRNA/s), thereby repressing its expression [57]. A single miRNA may regulate multiple targets and thus act as a chief controller of gene expression. Human genes (about 30\%) can be regulated by miRNAs as suggested by bioinformatic analysis, despite the constitution of 1-3\% miRNA of the human genome [58]. Several miRNA-coding genes operate as independent transcription units, which contain their own promoters and regulatory elements. However, about a quarter of miRNA genes are intronic and transcribed alongside their host genes [59].

Like proteins, genes coding for miRNAs are contained in the nucleus. miRNA can be synthesized from the introns of a functional gene coding for a specific mRNA or from its own gene (Fig. 3). The same enzyme that produces mRNA (RNA polymerase II) transcribes each gene of coded miRNA resulting in a primary miRNA 


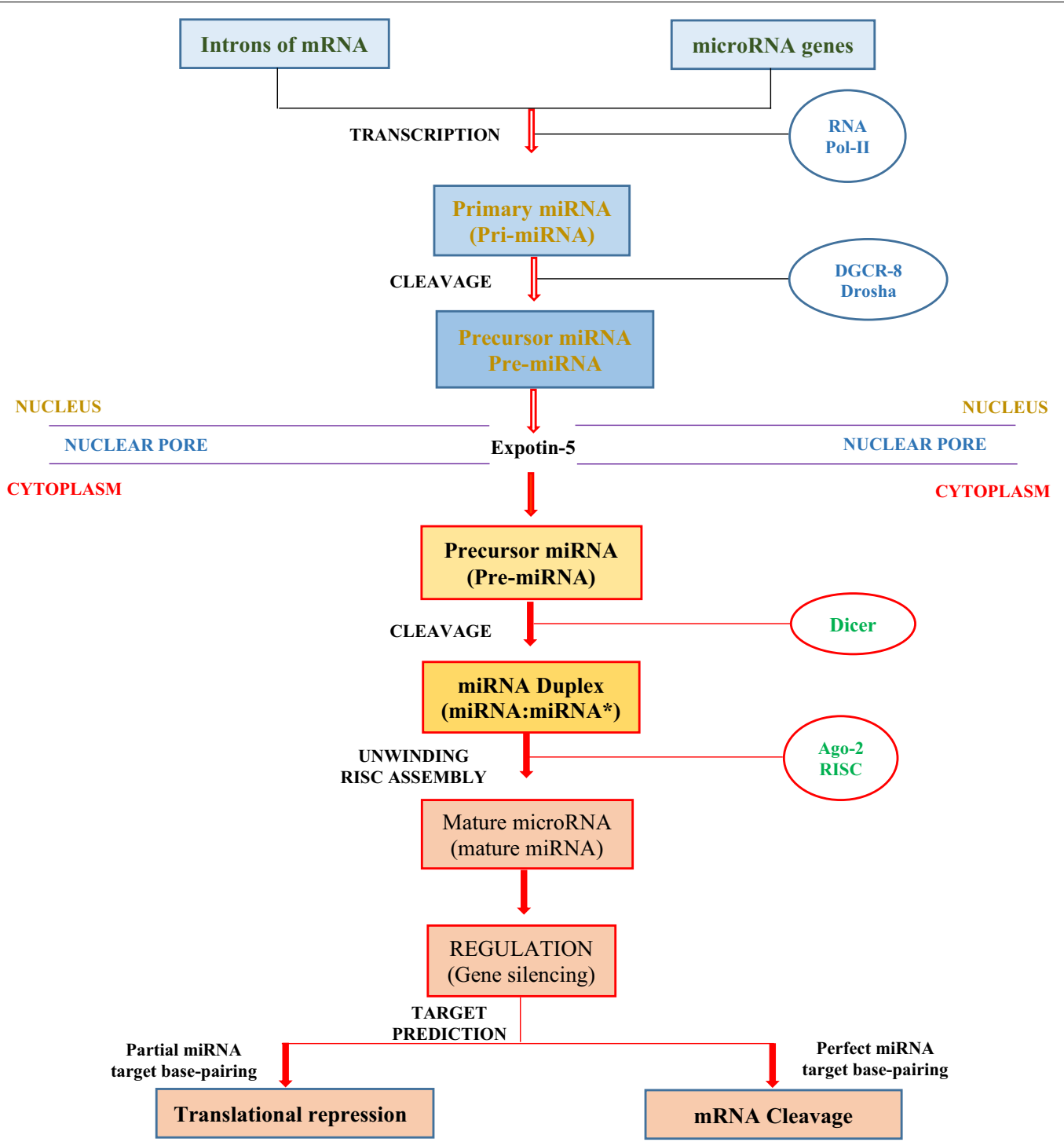

Fig. 3 The schematic diagram shows the synthesis and mode of regulation of miRNA from the nucleus to the cytoplasm. The spherical cycles indicate the proteins/enzyme and co-factors responsible for the synthesis of the molecule. Also, the big spherical cycle at the beginning of the reaction indicated that the enzyme is responsible for both mRNA and miRNA synthesis. DGCR-8 DiGeorge syndrome Critical Region 8 protein, AGO-2 argonaute protein

(pri-miRNA), which consists of a $5^{\prime}$ G-cap, at least an approximately 60-70-nucleotide hairpin structure and a $3^{\prime}$ poly (A) tail [60]. Polycistronic pri-mRNA may contain up to seven hairpin structures that produce different mature miRNAs. This pri-mRNA is the final microRNA with regulatory function after several steps. After transcription, the double-stranded stem is recognized by the cofactor DiGeorge syndrome Critical Region 8 protein (DGCR8). An enzyme (Drosha) associates with DGCR8 to form a microprocessing complex capable of cutting the pri-miRNA into a smaller precursor miRNA (premiRNA) by the removal of $5^{\prime}$ cap, the $3^{\prime}$ poly (A) tail and sequences flanking the hairpin structure. PrecursormiRNA is then moved from the nucleus through the nuclear pore to the cytoplasm with the aid of Exportin 5 , moves where it inactivates mRNA of one or multiple genes [61]. In the cytoplasm, the stem-loop of the premiRNA is further cleaved by a large microRNA protein called dicer (an endoribonuclease) to form a short double-stranded microRNA molecule (about 20-25 nucleotides long) consisting of mature miRNA strand and its complementary strand [62].

Consequently, argonaute protein (AGO-2) interacts with dicer to bind the mature miRNA due to the 
asymmetric thermostability. The miRNA is unwound, and one strand is released (the passenger strand). The guide strand interacts with AGO-2 (responsible for the endonuclease activity that induces mRNA cleavage) and some additional proteins to form the RNA Induced Silencing Complex (RISC). This is guided to the mRNA target to activate one or multiple genes [63]. The mRNA of a target gene is complementary to the sequence of the miRNA that enables base pairing. Complete and partial complementarity between the seed region (nucleotide positions 2-8) of miRNA and its target mRNAs results in mRNA degradation and translational inhibition or repression, respectively [64]. In the case of translational inhibition or repression, the RISC complex prevents the ribosome subunit from binding. The mechanism by which RISC induces translational repression is more complex and may include cap-dependent inhibition of translation initiation, eukaryotic translation initiation factor- 6 recruitment to RISC, nascent protein degradation, ribosomal drop-off and prevention of the interaction between poly (A)-binding proteins and eukaryotic translation initiation factor-4G subsequent to mRNA deadenylation $[64,65]$. In both cases (mRNA degradation and translational inhibition or repression), the mRNA will not be translated into a protein and the gene is silenced. Since their discovery in the 1900s, major parts of the miRNA's pathways still remain unclear. However, with their essential role in many biological processes (metabolism, stem cell division, development, apoptosis, cell proliferation, cell cycle control and cell stem differentiation), mRNA offers great potential in medicine and might lead to key treatment of various diseases in the future.

\section{General functions of miRNA}

Several biological functions of miRNA have been reported to be related to various disease mechanisms, regulation of cellular activities and cancer progression [66-69].

Seed region of about 2-8 nucleotides base pair allows miRNAs to bind at different degrees of complementarity. These therefore enables the recognition and binding of a variety of mRNAs which potentially regulate translation and expression of its protein products. Any change in the levels of a specific miRNA expression affects several biological pathways. Partial base pairing inhibits translation without interfering with the integrity of mRNA [70]. The observed discrepancies between mRNA and protein expression levels may be explained by the miRNA action, and the information on miRNA expression and function suggests the regulation of protein expression.

miRNAs are involved in various biological activities including cell differentiation, proliferation, apoptosis, and migration, which are key regulators in various pathogenesis and progression of different diseases, especially cancers [71-73]. miR-15 and miR-16, the first two miRNAs associated with cancer, play a significant role in the regulation of apoptosis by targeting the anti-apoptotic bcl-2 mRNA [74]. Also, the expression of human Ras, regulated by let-7 in cell culture, was also reported as the first miRNA-target interaction with relevance to cancer [75]. Subsequently, numerous publications have reported the role of miRNAs in tumors [76-80].

\section{miRNA tumor-specific metabolic reprogramming}

Cancer cells are shown to experience characteristic changes in their metabolic programs suggesting that metabolic shifts supports tumor cells growth and survival [81]. Report have it that the miRNA expression patterns in human cancers are not the same and that different cancer types have distinct expression patter [82]. This is so because the processing of primary miRNA transcripts to mature RNA is transcribed by RNA polymerase II (Fig. 3). This RNA polymerase II is also responsible for the transcription of mRNAs. Several alterations in miRNA levels have been revealed between colorectal cancer and normal colonic mucosa [83-85]. Gao et al. [86] reported that the c-Myc oncogenic transcription factor, which is known to regulate microRNAs and stimulate cell proliferation, transcriptionally represses miR-23a and miR-23b, resulting in greater expression of their target protein. Interestingly, c-Myc directly binds to the transcription subunit of microRNA (miR)-23a/b and subsequently contributes to the up-regulation of mitochondrial glutaminase 1 via the induction of ASCT2/ SLC1A5 transporter. Moreover, the association of c-Myc with miR-17-92 cluster has been shown to inhibit the activity of phosphatase and tensin homologue deleted on chromosome 10 (PTEN) and activates PI3K-Akt-mTOR axis leading to cell survival in early stage adenoma in CRC [87]. The complex crosstalk between miRNA and Myc is considered to be partially responsible for metabolic reprogramming. In addition, metformin induces miR-27b-mediated suppression of ENPP1, which reduces chemoresistance and tumor seeding potential [88].

\section{Expression of specific miRNAs in cancer}

Understanding the deregulation of miRNA expression observed in cancer cells is crucial. Studies have confirmed that when a miRNA is down-regulated in cancer and targets an oncogene, it may act as a tumor suppressor, or may act as an oncogene when up-regulated and targets a tumor suppressor or a gene important for differentiation [89-91].

Carden et al. [92] reported that increased miR-663 expression in breast tumors consistently correlates with 
increased patient survival, which demonstrates its epigenetic regulation and role in breast tumorigenesis. Also, miR-663a down-regulation was observed in human nonsmall cell lung cancer progression by targeting AP-1 component JunD in the cancer cells [93]. miR-34a, a chief regulator of tumor suppression, maintains its own expression levels through upstream signaling and activate tumor suppressor pathways, which are regulated by p 53 [94]. Wiggins et al. [95] reported that this miRNA inhibits cancer cells lacking endogenous p53.

miRNA has also been implicated in the repression of over 700 transcripts associated with cellular proliferation, survival, and plasticity [96]. High expression of miR21 predicts poor survival in CRC patient [97-101]. In a contradicting report of Lee et al. [102], the expression of miR-21 in the periphery of primary tumors demonstrated the significance of miRNA as a better prognosis in patients with advanced stage CRC. Molecular validation result of miR-22 expression revealed a significant increase in gastric cancer tissues when compared to adjacent non-cancerous tissues, and that low expression of miR-22 is associated with aggressive gastric cancer phenotype and its poor survival [103]. As suggested in previous studies, miR-22 is associated with several cellular processes, and their deregulation is a hallmark of several human cancers such as ovarian, prostate, colon and liver cancers [104-106]. James et al. [107] also reported the clinical utility of miR-21 and let- $7 \mathrm{~g}$ in prostate cancer. $\mathrm{Li}$ et al. [108] investigated the level and role of miR-106a expression in pancreatic cancer and reported that pancreatic cancer cell invasion was dependent on miR-106a regulation $[109,110]$.

\section{Diet interaction with microRNAs in colorectal cancer}

Research on the discovery of drugs for the treatment of cancer is still ongoing, with several shortcomings due to the complex genetic and epigenetic events involved in its pathogenesis. However, strong evidence continues to show that certain dietary components possess cancerprotective capabilities, including therapeutic and chemopreventive properties. These dietary factors may play a role in several stages of carcinogenesis, such as cell-cycle modulation, inflammation, apoptosis, DNA repair and angiogenesis [111]. miRNAs are intrinsically involved in similar stages of carcinogenesis, which widens the understanding between miRNAs and certain dietary components (Fig. 4). Certain dietary components of plant origin may be less bio-available and thus, escape digestion into the large intestine. Therefore, these bioactive components may then play a role in modulating CRC.

\section{Resveratrol}

Resveratrol, polyphenols found largely in the skin of grapes, raspberries, mulberries, and blueberries, are generally considered to have several health benefits due to its antioxidative properties. Few studies have shown the potential role of resveratrol against colon cancer. Treatment of SW480 colon cancer cells with $50 \mu \mathrm{M}$ of resveratrol for $14 \mathrm{~h}$ prevented the expression of several oncogenic miRNAs, such as miR-21 which is induced in chronic inflammation [112]. Furthermore, the expression of a tumor-suppressor miRNA, miR-663, was significantly higher in cancer cells when its expression was compared to untreated cells. The use of resveratrol in the treatment of colon cancer cells has led to a reduction in TGF $\beta 1$ and its downstream effector SMAD3, this could be explained by the target of miR-663 on TGF $\beta 1$ transcripts [112]. This finding on miR-663 is of significance since activation of the TGF $\beta 1$ pathway increases angiogenesis and metastasis in later stages of cancer $[112,113]$. In addition, resveratrol was also shown to inhibit the up-regulation of miR-122, an oncogenic and inflammation-induced miRNA, which is dependent manner on miR-663 [114]. Another study showed that resveratrol inhibited the growth of human colon cancer cells by upregulating miR-34a, which in turn down-regulated the E2F3 and Sirt1 genes [115]. Therefore, resveratrol possesses anti-inflammation and anti-cancer capabilities, which might be linked to its antioxidative properties.

\section{Fatty acids}

Short-chain fatty acids (SCFAs) and omega-3 fatty acids have been shown to have cancer-protective properties. Short-chain fatty acids are important end products of the gut microbial fermentation of non-digestible carbohydrates in the diet. Butyrate most importantly is vital for the proliferation and sustenance of colonic epithelial cells. As such, several studies have reported the involvement of microbial-derived butyrate from dietary fiber fermentation as a histone deacetylase (HDAC) inhibitor and thus plays a protective role against colorectal tumorigenesis [116-118]. However, the chemoprotective effect of butyrate on specific miRNAs remains to be fully elucidated. In human colon carcinoma cells, microarray analysis revealed that treatment with $2 \mathrm{mM}$ butyrate changed the levels of various aberrantly expressed miRNAs [119]. Notably, butyrate treatment decreased the expression of miR-106a and miR-106b, which was accompanied by a reduction in cell proliferation [119]. Furthermore, in other human colon cancer models, treatment with 1-25 mM butyrate attenuated the expression of an oncogenic miR-17-92 cluster of miRNAs, while inhibiting cell differentiation and promoting apoptosis [120, 121]. 


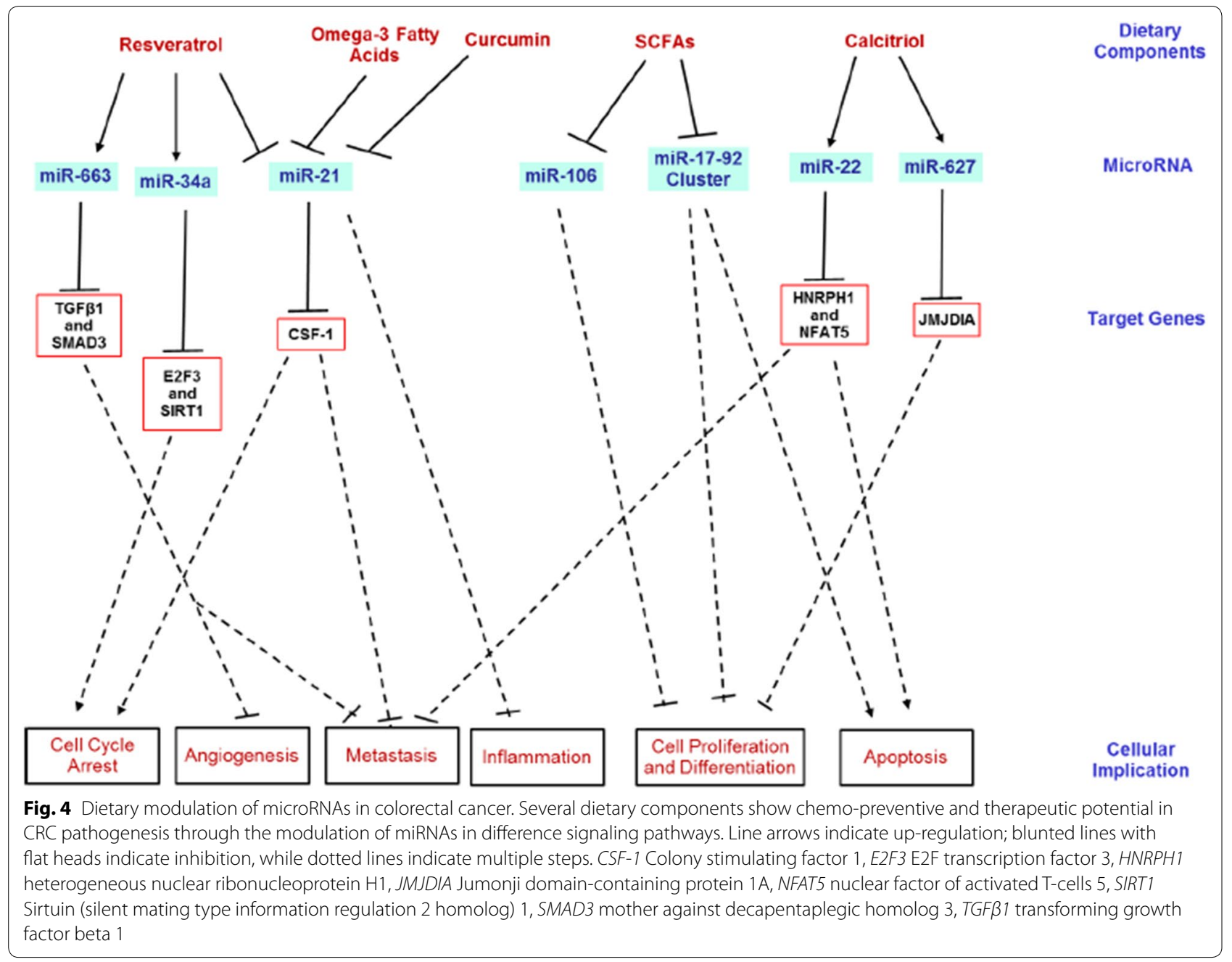

Omega-3 fatty acids may have protective effect against inflammatory diseases, including cancer [122, 123]. Specifically, it was reported that fish oil prevented the down-regulation of several miRNAs in the colon of rats 34-weeks post-injection with azoxymethane. Such miRNAs include miR-15b, miR-107, let-7d, miR-191, and miR-324-5p. This effect corresponds to a significant reduction in colon tumorigenesis [124]. Similarly, the expression of miR-21 was significantly diminished in breast cancer cell lines treated with fish oil, thus repressing CSF-1 levels which have a significant role in breast tumorigenesis and metastasis [125]. Put together, these findings strongly suggest the chemo-preventive potential of SCFAs and omega-3 fatty acids (that could be obtained through the diet).

\section{Curcumin}

Curcumin, a phytochemical found in turmeric, has been widely studied for its several health benefits, including antioxidant, anti-inflammatory and anti-cancer properties. Studies have also reported miRNA modulation in various cancer models. Recently, curcumin was reported to reduce the expression of miR-21, which is over-expressed in many tumors leading to cancer progression and metastasis [126]. Treatment of human colon carcinoma cells (HCT-116) with curcumin reduced miR21 activity in a dose-dependent manner, thereby leading to cell cycle arrest at the $G_{2} / M$ phase, thus reducing cell proliferation and tumor growth [126]. A similar effect of curcumin on miR-21 was also reported in a pancreatic cancer cell model [127]. Other studies have also reported the beneficial effect of curcumin in miRNA modulation in various cancer models, including pancreatic cancer [127-129] and lung cancer [130].

\section{Vitamin D}

Vitamins A, D, and E have been reported to play an anti-cancer role involving the modulation of miRNAs [131, 132], amongst which vitamin $\mathrm{D}$ have an active chemo-preventive role in CRC development. Early 
epidemiological evidence suggested an inverse relationship between vitamin D levels and CRC [133]. Further studies in human colon cancer cells revealed that treatment with $10 \mu \mathrm{M}$ calcitriol (an active form of vitamin D) induced miR-22 expression which further inhibits cell proliferation and migration. These effects were time- and dose-dependent, and also dependent on the activation of vitamin D receptor [134]. Moreover, up-regulation of miR-22 by vitamin $\mathrm{D}$ in the colon cancer cells is necessary for the repression of several vitamin D target genes, such as HNRPH1 and NFAT5, which mediate apoptosis inhibition and cancer invasion, respectively [134]. In addition, the expression of miR-627 was up-regulated following incubation of human CRC cells (HT-29) with calcitriol, which down-regulates JMJD1A (a gene involved in histone methylation), and prevent cell proliferation and differentiation [135]. Thus, current knowledge posits that vitamin D has cancer-suppressive potentials, which may be mediated via microRNA activation.

\section{Selenium}

Selenium is an essential trace mineral with an antioxidant activity, which was shown to be beneficial in promoting cardiac health and preventing cancer development [136]. Although its role in cancer prevention has been widely reported [136], little is known about its effect on miRNA activity in cancer models. Of note, incubation of human prostate cancer cells (LNCaP) with sodium selenite $(2.5 \mu \mathrm{M})$ up-regulated members of the miR-34 family, resulting in a selenium-induced expression and activation of the tumor-suppressor p53, and its downstream targets [137]. Other metabolites of selenium, including methylselenocysteine and selenomethionine, have been found to possess HDAC-inhibiting activity in human colon cancer cells [138], but the knowledge of possible miRNAs involved is still vague.

\section{Soy isoflavones}

Diadzein, genistein, and glycitein are soy isoflavones that were reported to have anti-tumor properties via the modulation of the estrogen receptor [131]. Their chemopreventive and anti-metastasis potential via the modulation of miRNAs was reported in pancreatic cancer [139], prostate cancer [140], and ovarian cancer [141] models. It is interesting to investigate the potential role of the soy isoflavones in colon cancer, since these isoflavones act via the modulation of estrogen receptor. It was suggested that an up-regulation of the estrogen receptor beta (ER $\beta)$ signaling in SW480 colon cancer cells showed antiproliferative effects by silencing the effect of oncogenic miRNAs [142].

\section{Ellagitannin}

Ellagitannins are hydrolyzable polymeric polyphenols found in many fruits and nuts. Initial characterization of ellagitannins showed their potent antioxidant, antiinflammatory, anti-proliferation and pro-apoptotic capabilities [143]. More recently, ellagitannin was shown to possess anti-neoplastic properties in a human liver cancer cell line HepG2, while modulating the expression of 25 miRNAs [144]. However, the specific mechanisms of the ellagitannin-miRNA interplay in cancer is still unknown.

\section{Caloric restriction}

Caloric restriction (CR) generally refers to a $\leq 60 \%$ dietary energy deficit without malnutrition [145]. The beneficial effects of CR have been reported in various conditions, including aging and cancer. $\mathrm{CR}$ has long been known to play a vital role in colon cancer prevention, but specific mechanisms and miRNAs involved still requires further evaluation [146, 147]. The anti-cancer effects of $\mathrm{CR}$ may be due to its influence on cellular senescence [148]. The Hayflick limit, which described cellular senescence as a stable cell cycle arrest regardless of growth conditions, was thought to protect against the heightened proliferation of cancer cells $[149,150]$. In paradox, senescent cells may also contribute to tumorigenesis in various tissues, through the production of an array of cytokines, chemokines, proteases and growth factors, collectively referred to as the senescence-associated secretory phenotype (SASP) [151, 152]. Unsurprisingly, $N F \kappa \beta$ is known to play a role in regulating various inflammatory pathways involved in producing the senescence secretome, that drives the chronic low-grade inflammation capable of driving tumor initiation and progression [153, 154].

Some of the consequences of overnutrition-induced obesity are hyperinsulinemia and hyperleptinemia, resulting in insulin and leptin resistance respectively. These may serve as growth factors leading to the activation of $N F \kappa \beta$, thus leading to chronic inflammation characteristic of many tumors [154-156]. On the other hand, CR may impact the obesity-cancer pathway, by reducing serum insulin, leptin, and associated inflammation by limiting $N F \kappa \beta$-related gene expression [157, 158]. Specifically, injection of mice on a $30 \%$ CR diet with MC38 colon tumor cells, led to a reduction in tumor size, serum growth factors and a downregulation of inflammatory genes induced by NFk $\beta$ [157]. Similarly, 5 -week feeding of a $30 \% \mathrm{CR}$ diet in mice showed inhibitory effects on pancreatic tumor growth, IGF-1 and NFk $\beta$ related inflammatory gene expression [158]. Still, possible miRNAs involved in the anti-tumor effects of CR in relation to the NFk $\beta$-SASP pathway are still largely 
unclear. Few breast cancer models have shown that $\mathrm{CR}$ may impact miRNAs, by showing inhibitory effects on $\mathrm{miR} 17 / 20 \mathrm{a}$ and miR200a, leading to a reduction in extracellular matrix proteins, tumor progression and metastasis $[159,160]$. Put together, it may be hypothesized that CR possesses anti-cancer effects by decreasing chronic inflammation through the limitation of $\mathrm{NF} \kappa \beta$ activity in senescent cells. However, this concept, potential mechanisms, and miRNAs involved are interesting subjects for future studies. Understanding this effect of CR may be important in preventing colorectal cancer and other cancers in our obese and older adult populations where lowgrade inflammation and cellular senescence are more observed, respectively.

\section{Conclusion}

It is now a known fact that CRC is a major depravity that affects the world based on lifestyle changes and sometimes based on age or hereditary factors. Regular screening for CRC is essential and should be done to detect tumor early before it metastasizes. Several screening and treatment methods have been employed for CRC, which have been of help to date but present several limitations. Recently, the involvement of 18-22 nucleotide to the foreknown miRNA, and its relation to dietary factors and tumorigenesis. This microRNA can be differentially and commonly expressed depending on its stage and location of the tumor. The ability of microRNA to differentiate between CRC patients and healthy patients in a non-invasive approach for CRC detection makes it a good diagnostic biomarker. Currently, little is known on the impact of diet on miRNAs in CRC, as most studies were only centered on in vitro models. Studies providing information on the use of miRNA-specific knockout should be considered in various in vivo models. Apart from the few described in this review, other dietary components such as folate and methyl-deficient diets, indoles and isothiocyanates (from cruciferous vegetables) and tea catechins have been widely shown to possess chemo-preventive properties but their effect via the modulation of microRNAs in the colon and rectal cancer is still unclear. Collectively, bioactive components from the diet modulate several miRNAs which are involved in cancer development and growth via several mechanisms. Due to their potent chemo-preventive properties, it is therefore pertinent for public health specialists and health organizations to consider incorporating these dietary components into the nutrition sensitization program to prevent or reduce the menace of CRC and other malignancies.

\section{Abbreviations}

CRC: colorectal cancer; miRNAs: microRNAs; RISC: RNA-induced silencing complex; UTR: the 3'untranslated region; DGCR-8: DiGeorge syndrome Critical
Region 8 protein; AGO-2: argonaute protein; ERß: estrogen receptor beta; SCFAs: short-chain fatty acids; CASP3: cysteine-aspartic acid protease 3; APC: adenomatous polyposis coli; MMPs: matrix metalloproteinases; DCC: deleted in colorectal carcinoma; EGFR: epidermal growth factor receptor; ICAM: intercellular adhesive molecules; PDCD4: programmed cell death 4; PTEN: phosphatase and tensin homolog; CDK4,6: cyclin-dependent kinase 4,6; ECM: extracellular matrix; EMT: epithelial-to-mesenchymal transition; RECK: reversion-inducing cysteine-rich protein with kazal motifs; TIMP3: tissue inhibitor of metalloproteinase 3; UPAR: plasminogen activator, urokinase receptor; TGF $\beta R$ I/ II: transforming growth factor ßreceptor I/II; ZEB1/2: zinc-finger E-box binding homeobox-1; CTGF: connective tissue growth factor; TSP1: thrombospondin-1.

\section{Authors' contributions}

$\mathrm{AF}$ and $\mathrm{AP}$ conceived the concept, design, and first draft of the study. BO helped with the constitution of the Dietary analysis part of the review, ET and OA contributed to the revision and critical intellectual contents. All authors contributed significantly. All authors read and approved the final manuscript

\section{Author details}

${ }^{1}$ Department of Biotechnology, Faculty of Natural Sciences, University of the Western Cape, Cape Town, South Africa. ${ }^{2}$ Department of Nutritional Science, Oklahoma State University, 301, Human Sciences, Stillwater, OK

74075, USA. ${ }^{3}$ Department of Biochemistry, Afe Babalola University, P.M.B. 5454, Ado-Ekiti, Ekiti State, Nigeria. ${ }^{4}$ Institute of Biochemistry II, Medical Faculty, University of Cologne, Joseph-Stelzmann Str. 52, 50931 Cologne, Germany. ${ }^{5}$ Biotechnology Innovation Division, Aminotek PTY LTD, Suite 2C, Oude Westhof Village Square, Bellville 7530, South Africa.

\section{Acknowledgements}

Authors will like to appreciate the contributions of the following for their support both with scientific materials, emotionally and physically. Bioinformatics Research Group of the University of the Western Cape, Dr. Taiwo D. Akinsoji (MBBS), Dr. Ashwil Klein, and The School of Post Graduate Studies, University of the Western Cape for their 1-week publication retreat.

\section{Competing interests}

The authors declare that they have no competing interests.

Availability of data and materials

Not applicable.

Consent for publication

Not applicable.

Ethics approval and consent to participate

Not applicable.

Funding

Not applicable.

\section{Publisher's Note}

Springer Nature remains neutral with regard to jurisdictional claims in published maps and institutional affiliations.

Received: 22 June 2018 Accepted: 31 August 2018

Published online: 06 September 2018

\section{References}

1. Arnold M, Sierra MS, Laversanne M, Soerjomataram I, Jemal A, Bray F. Global patterns and trends in colorectal cancer incidence and mortality. Gut. 2016. https://doi.org/10.1136/gutjnl-2015-310912.

2. Brand M, Gaylard P, Ramos J. Colorectal cancer in South Africa: an assessment of disease presentation, treatment pathways and 5-year survival. SAMJ S Afr Med J. 2018;108:118-22.

3. Bray F, Jemal A, Grey N, Ferlay J, Forman D. Global cancer transitions according to the Human Development Index (2008-2030): a population-based study. Lancet Oncol. 2012;13:790-801. 
4. Alwan A. Global status report on noncommunicable diseases 2010. Geneva: World Health Organization; 2011.

5. Saluja S, Alatise OI, Adewale A, Misholy J, Chou J, Gonen M, Weiser $M$, Kingham TP. A comparison of colorectal cancer in Nigerian and North American patients: is the cancer biology different? Surgery. 2014;156:305-10.

6. CECP-Nigeria. Colon cancer prevention in Nigeria—an achievable goal. Guardiance Newspaper, @ 2015 Committee Encouraging Corporate Philanthropy (CECP-Nigeria). 2015.

7. Ahmed FE, Jeffries CD, Vos PW, Flake G, Nuovo GJ, Sinar DR, Naziri W, Marcuard SP. Diagnostic microRNA markers for screening sporadic human colon cancer and active ulcerative colitis in stool and tissue. Cancer Genom Proteom. 2009;6:281-95.

8. Song L-L, Li Y-M. Current noninvasive tests for colorectal cancer screening: an overview of colorectal cancer screening tests. World J Gastrointest Oncol. 2016:8:793.

9. Lieberman D. Progress and challenges in colorectal cancer screening and surveillance. Gastroenterology. 2010;138:2115-26.

10. Heo J, Jeon SW, Jung MK, Kim SK, Kim J, Kim S. Endoscopic resection as the first-line treatment for early colorectal cancer: comparison with surgery. Surg Endosc. 2014;28:3435-42.

11. Vukobrat-Bijedic Z, Husic-Selimovic A, Sofic A, Bijedic N, Bjelogrlic I, Gogov B, Mehmedovic A. Cancer antigens (CEA and CA 19-9) as markers of advanced stage of colorectal carcinoma. Med Arch. 2013;67:397.

12. Sovich $\mathrm{J}$, Sartor Z, Misra S. Developments in screening tests and strategies for colorectal cancer. BioMed Res Int. 2015. https://doi. org/10.1155/2015/326728.

13. Kawamura M, Toiyama Y, Tanaka K, Inoue Y, Kusunoki M. Can circulating microRNAs become the test of choice for colorectal cancer? Curr Colorectal Cancer Rep. 2014;10:403-10.

14. Reddy KB. MicroRNA (miRNA) in cancer. Cancer Cell Int. 2015:15:38.

15. Hou N, Huo D, Dignam JJ. Prevention of colorectal cancer and dietary management. Chin Clin Oncol. 2013:2:13.

16. Stewart B, Wild CP. World cancer report 2014. Geneva: World Health Organisation; 2017.

17. Winawer SJ, Zauber AG. The advanced adenoma as the primary target of screening. Gastrointest Endosc Clin. 2002;12:1-9.

18. Levine JS, Ahnen DJ. Adenomatous polyps of the colon. N Engl J Med. 2006:355:2551-7.

19. Pickhardt PJ, Kim DH, Pooler BD, Hinshaw JL, Barlow D, Jensen D, Reichelderfer M, Cash BD. Assessment of volumetric growth rates of small colorectal polyps with CT colonography: a longitudinal study of natural history. Lancet Oncol. 2013;14:711-20.

20. Mundade R, Imperiale TF, Prabhu L, Loehrer PJ, Lu T. Genetic pathways, prevention, and treatment of sporadic colorectal cancer. Oncoscience. 2014;1:400

21. Rothwell PM, Wilson M, Elwin C-E, Norrving B, Algra A, Warlow CP, Meade TW. Long-term effect of aspirin on colorectal cancer incidence and mortality: 20-year follow-up of five randomised trials. Lancet. 2010;376:1741-50.

22. Yang T, Owen JL, Lightfoot YL, Kladde MP, Mohamadzadeh M. Microbiota impact on the epigenetic regulation of colorectal cancer. Trends Mol Med. 2013:19:714-25.

23. Arends MJ. Pathways of colorectal carcinogenesis. Appl Immunohistochem Mol Morphol. 2013:21:97-102.

24. Cheetham S, Gruhl F, Mattick J, Dinger M. Long noncoding RNAs and the genetics of cancer. Br J Cancer. 2013;108:2419.

25. Mazeh H, Mizrahi I, llyayev N, Halle D, Brücher BL, Bilchik A, Protic M, Daumer M, Stojadinovic A, Avital I. The diagnostic and prognostic role of microRNA in colorectal cancer-a comprehensive review. J Cancer. 2013;4:281.

26. Xie X, Tang B, Xiao Y-F, Xie R, Li B-S, Dong H, Zhou J-Y, Yang S-M. Long non-coding RNAs in colorectal cancer. Oncotarget. 2016;7:5226.

27. Zhang J, Zhang A, Wang Y, Liu N, You Y, Kang C, Pu P. New insights into the roles of ncRNA in the STAT3 pathway. Future Oncol. 2012;8:723-30.

28. Wapinski $\mathrm{O}$, Chang HY. Long noncoding RNAs and human disease. Trends Cell Biol. 2011;21:354-61.

29. Prensner JR, Chinnaiyan AM. The emergence of IncRNAs in cancer biology. Cancer Discov. 2011;1:391-407.
30. Liu Q, Huang J, Zhou N, Zhang Z, Zhang A, Lu Z, Wu F, Mo Y-Y. LncRNA loc285194 is a p53-regulated tumor suppressor. Nucleic Acids Res. 2013:41:4976-87.

31. Gupta RA, Shah N, Wang KC, Kim J, Horlings HM, Wong DJ, Tsai M-C, Hung T, Argani P, Rinn JL. Long non-coding RNA HOTAIR reprograms chromatin state to promote cancer metastasis. Nature. 1071;2010:464.

32. Zhang L, Yang F, Yuan J-H, Yuan S-X, Zhou W-P, Huo X-S, Xu D, Bi $\mathrm{H}-\mathrm{S}$, Wang F, Sun S-H. Epigenetic activation of the MiR-200 family contributes to H19-mediated metastasis suppression in hepatocellular carcinoma. Carcinogenesis. 2012;34:577-86.

33. Zhou Y, Zhong Y, Wang Y, Zhang X, Batista DL, Gejman R, Ansell PJ, Zhao J, Weng C, Klibanski A. Activation of p53 by MEG3 non-coding RNA. J Biol Chem. 2007;282:24731-42.

34. Ling H, Spizzo R, Atlasi Y, Nicoloso M, Shimizu M, Redis R, Nishida N, Gafà R, Song J, Guo Z. CCAT2, a novel non-coding RNA mapping to $8 \mathrm{q} 24$, underlies metastatic progression and chromosomal instability in colon cancer. Genome Res. 2013. https://doi.org/10.1101/gr.15294 2.112.

35. Zheng J, Li X-D, Wang P, Liu X-B, Xue Y-X, Hu Y, Li Z, Li Z-Q, Wang Z-H, Liu $Y-H$. CRNDE affects the malignant biological characteristics of human glioma stem cells by negatively regulating miR-186. Oncotarget. 2015;6:25339.

36. Hanahan D, Weinberg RA. Hallmarks of cancer: the next generation. Cell. 2011;144:646-74.

37. Wu WK, Wang XJ, Cheng AS, Luo MX, Ng SS, To KF, Chan FK, Cho CH, Sung JJ, Yu J. Dysregulation and crosstalk of cellular signaling pathways in colon carcinogenesis. Crit Rev Oncol Hematol. 2013:86:251-77.

38. Kong YW, Ferland-McCollough D, Jackson TJ, Bushell M. microRNAs in cancer management. Lancet Oncol. 2012;13:e249-58.

39. Michael MZ, O'Connor SM, van Holst Pellekaan NG, Young GP, James RJ. Reduced accumulation of specific MicroRNAs in colorectal Neoplasia1 1 Note: Susan M. O'Connor and Nicholas G. van Holst Pellekaan contributed equally to this work. Mol Cancer Res. 2003;1:882-91.

40. Cawley K, Logue SE, Gorman AM, Zeng Q, Patterson J, Gupta S, Samali A. Disruption of microRNA biogenesis confers resistance to ER stress-induced cell death upstream of the mitochondrion. PLoS ONE. 2013:8:e73870

41. Cummins JM, He Y, Leary RJ, Pagliarini R, Diaz LA, Sjoblom T, Barad O, Bentwich Z, Szafranska AE, Labourier E. The colorectal microRNAome. Proc Natl Acad Sci. 2006;103:3687-92.

42. Wang C-J, Zhou Z-G, Wang L, Yang L, Zhou B, Gu J, Chen H-Y, Sun X-F. Clinicopathological significance of microRNA-31,-143 and-145 expression in colorectal cancer. Dis Markers. 2009;26:27-34.

43. Schepeler T, Reinert JT, Ostenfeld MS, Christensen LL, Silahtaroglu AN, Dyrskjøt L, Wiuf C, Sørensen FJ, Kruhøffer M, Laurberg S. Diagnostic and prognostic microRNAs in stage II colon cancer. Cancer Res. 2008:68:6416-24

44. Bandrés E, Cubedo E, Agirre X, Malumbres R, Zarate R, Ramirez N, Abajo A, Navarro A, Moreno I, Monzo M. Identification by real-time PCR of 13 mature microRNAs differentially expressed in colorectal cancer and non-tumoral tissues. Mol Cancer. 2006:5:29.

45. Zhang H, Li Y, Huang Q, Ren X, Hu H, Sheng H, Lai M. MiR-148a promotes apoptosis by targeting $\mathrm{BCl}-2$ in colorectal cancer. Cell Death Differ. 2011;18:1702

46. Chen Y, Song Y, Wang Z, Yue Z, Xu H, Xing C, Liu Z. Altered expression of MiR-148a and MiR-152 in gastrointestinal cancers and its clinical significance. J Gastrointest Surg. 2010;14:1170-9.

47. Siemens H, Neumann J, Jackstadt R, Mansmann U, Horst D, Kirchner $\mathrm{T}$, Hermeking $\mathrm{H}$. Detection of miR-34a promoter methylation in combination with elevated expression of $\mathrm{c}-\mathrm{Met}$ and $\beta$-catenin predicts distant metastasis of colon cancer. Clin Cancer Res. 2012. https://doi. org/10.1158/1078-0432.CCR-12-1703.

48. Lu Y-X, Yuan L, Xue X-L, Zhou M, Liu Y, Zhang C, Li J-P, Zheng L, Hong M, Li X-N. Regulation of colorectal carcinoma stemness, growth, and metastasis by an miR-200c-Sox2-negative feedback loop mechanism. Clin Cancer Res. 2014. https://doi.org/10.1158/1078-0432.CCR-13-2348.

49. Lujambio A, Calin GA, Villanueva A, Ropero S, Sánchez-Céspedes M, Blanco D, Montuenga LM, Rossi S, Nicoloso MS, Faller WJ. A microRNA DNA methylation signature for human cancer metastasis. Proc Natl Acad Sci. 2008:105:13556-61. 
50. Siemens H, Jackstadt R, Hünten S, Kaller M, Menssen A, Götz U, Hermeking H. miR-34 and SNAIL form a double-negative feedback loop to regulate epithelial-mesenchymal transitions. Cell Cycle. 2011;10:4256-71.

51. Rokavec M, Öner MG, Li H, Jackstadt R, Jiang L, Lodygin D, Kaller M, Horst D, Ziegler PK, Schwitalla S. IL-6R/STAT3/miR-34a feedback loop promotes EMT-mediated colorectal cancer invasion and metastasis. J Clin Invest. 2014;124:1853-67.

52. Hahn S, Jackstadt R, Siemens H, Hünten S, Hermeking H. SNAIL and miR-34a feed-forward regulation of ZNF281/ZBP99 promotes epithelial-mesenchymal transition. EMBO J. 2013;32:3079-95.

53. Okayama H, Schetter AJ, Harris CC. MicroRNAs and inflammation in the pathogenesis and progression of colon cancer. Dig Dis. 2012;30(suppl 2):9-15.

54. Nagy ZB, Wichmann B, Kalmár A, Galamb O, Barták BK, Spisák S, Tulassay Z, Molnár B. Colorectal adenoma and carcinoma specific miRNA profiles in biopsy and their expression in plasma specimens. Clin Epigenetics. 2017:9:22 (PMID: PMC5310023).

55. Esteller M. Non-coding RNAs in human disease. Nat Rev Genet. 2011;12:861.

56. Catalanotto C, Cogoni C, Zardo G. MicroRNA in control of gene expression: an overview of nuclear functions. Int J Mol Sci. 2016;17:1712.

57. Valinezhad Orang A, Safaralizadeh R, Kazemzadeh-Bavili M. Mechanisms of miRNA-mediated gene regulation from common downregulation to mRNA-specific upregulation. Int J Genom. 2014. https://doi. org/10.1155/2014/970607.

58. Carthew RW, Sontheimer EJ. Origins and mechanisms of miRNAs and siRNAs. Cell. 2009;136:642-55.

59. Wu WK, Law PT, Lee CW, Cho CH, Fan D, Wu K, Yu J, Sung JJ. MicroRNA in colorectal cancer: from benchtop to bedside. Carcinogenesis. 2010;32:247-53.

60. Lee Y, Kim M, Han J, Yeom KH, Lee S, Baek SH, Kim VN. MicroRNA genes are transcribed by RNA polymerase II. EMBO J. 2004;23:4051-60.

61. Kim VN. MicroRNA biogenesis: coordinated cropping and dicing. Nat Rev Mol Cell Biol. 2005;6:376

62. Siomi H, Siomi MC. Posttranscriptional regulation of microRNA biogenesis in animals. Mol Cell. 2010;38:323-32.

63. Eamens AL, Smith NA, Curtin SJ, Wang M-B, Waterhouse PM. The Arabidopsis thaliana double-stranded RNA binding protein DRB1 directs guide strand selection from microRNA duplexes. RNA. 2009;15:2219-35.

64. van den Berg A, Mols J, Han J. RISC-target interaction: cleavage and translational suppression. Biochim Biophys Acta (BBA) Gene Regul Mech. 2008:1779:668-77.

65. Wakiyama M, Takimoto K, Ohara O, Yokoyama S. Let-7 microRNA-mediated mRNA deadenylation and translational repression in a mammalian cell-free system. Genes Dev. 2007;21:1857-62.

66. Lizarbe MA, Calle-Espinosa J, Fernández-Lizarbe E, Fernández-Lizarbe S, Robles MÁ, Olmo N, Turnay J. Colorectal cancer: from the genetic model to posttranscriptional regulation by noncoding RNAs. BioMed Res Int. 2017. https://doi.org/10.1155/2017/7354260.

67. Huang Y, Shen XJ, Zou Q, Wang SP, Tang SM, Zhang GZ. Biological functions of microRNAs: a review. J Physiol Biochem. 2011;67:129-39.

68. Vidigal JA, Ventura A. The biological functions of miRNAs: lessons from in vivo studies. Trends Cell Biol. 2015;25:137-47.

69. MacFarlane L-A, Murphy PR. MicroRNA: biogenesis, function and role in cancer. Curr Genom. 2010;11:537-61.

70. Fabian MR, Sonenberg N, Filipowicz W. Regulation of mRNA translation and stability by microRNAs. Annu Rev Biochem. 2010;79:351-79.

71. Volinia S, Galasso M, Costinean S, Tagliavini L, Gamberoni G, Drusco A, Marchesini J, Mascellani N, Sana ME, Jarour RA. Reprogramming of miRNA networks in cancer and leukemia. Genome Res. 2010;20:589-99.

72. Bartel DP. MicroRNAs: target recognition and regulatory functions. Cell. 2009;136:215-33.

73. Di Leva G, Garofalo M, Croce CM. MicroRNAs in cancer. Annu Rev Pathol. 2014;9:287-314.

74. Cimmino A, Calin GA, Fabbri M, lorio MV, Ferracin M, Shimizu M, Wojcik SE, Aqeilan RI, Zupo S, Dono M. miR-15 and miR-16 induce apoptosis by targeting BCL2. Proc Natl Acad Sci. 2006. https://doi.org/10.1073/ pnas.0506654102.

75. Johnson SM, Grosshans H, Shingara J, Byrom M, Jarvis R, Cheng A, Labourier E, Reinert KL, Brown D, Slack FJ. RAS is regulated by the let-7 microRNA family. Cell. 2005;120:635-47.
76. Weiss CN, Ito K. A macro view of microRNAs: the discovery of microRNAs and their role in hematopoiesis and hematologic disease. Int Rev Cell Mol Biol. 2017;334:99-175.

77. Paladini L, Fabris L, Bottai G, Raschioni C, Calin GA, Santarpia L. Targeting microRNAs as key modulators of tumor immune response. J Exp Clin Cancer Res. 2016;35:103.

78. Calvin Li S, T Vu L, Jianying Luo J, F Zhong J, Li Z, A Dethlefs B, G Loudon W, H Kabeer M. Tissue elasticity bridges cancer stem cells to the tumor microenvironment through micrornas: implications for a "watch-andwait" approach to cancer. Curr Stem Cell Res Ther. 2017;12:455-70.

79. Lages E, Ipas H, Guttin A, Nesr H, Berger F, Issartel J-P. MicroRNAs: molecular features and role in cancer. Front Biosci. 2012;17:2508.

80. Gambari R, Brognara E, Spandidos DA, Fabbri E. Targeting oncomiRNAs and mimicking tumor suppressor miRNAs: new trends in the development of miRNA therapeutic strategies in oncology. Int $J$ Oncol. 2016:49:5-32

81. Fadaka A, Ajiboye B, Ojo O, Adewale O, Olayide I, Emuowhochere R. Biology of glucose metabolization in cancer cells. J Oncol Sci. 2017;3:45-51.

82. Lu J, Getz G, Miska EA, Alvarez-Saavedra E, Lamb J, Peck D, Sweet-Cordero A, Ebert BL, Mak RH, Ferrando AA. MicroRNA expression profiles classify human cancers. Nature. 2005;435:834.

83. Motoyama K, Inoue H, Takatsuno Y, Tanaka F, Mimori K, Uetake H, Sugihara K, Mori M. Over-and under-expressed microRNAs in human colorectal cancer. Int J Oncol. 2009:34:1069-75.

84. Rossi S, Kopetz S, Davuluri R, Hamilton SR, Calin GA. MicroRNAs, ultraconserved genes and colorectal cancers. Int J Biochem Cell Biol. 2010;42:1291-7.

85. Slaby O, Svoboda M, Michalek J, Vyzula R. MicroRNAs in colorectal cancer: translation of molecular biology into clinical application. Mol Cancer. 2009:8:102.

86. Gao P, Tchernyshyov I, Chang T-C, Lee Y-S, Kita K, Ochi T, Zeller KI, De Marzo AM, Van Eyk JE, Mendell JT. c-Myc suppression of miR-23a/b enhances mitochondrial glutaminase expression and glutamine metabolism. Nature. 2009:458:762.

87. Yoshida GJ. Emerging roles of Myc in stem cell biology and novel tumor therapies. J Exp Clin Cancer Res. 2018;37:173.

88. Yoshida GJ. Metabolic reprogramming: the emerging concept and associated therapeutic strategies. J Exp Clin Cancer Res. 2015;34:1.

89. Calin GA, Croce CM. MicroRNA-cancer connection: the beginning of a new tale. Cancer Res. 2006;66:7390-4.

90. Xishan Z, Ziying L, Jing D, Gang L. MicroRNA-320a acts as a tumor suppressor by targeting BCR/ABL oncogene in chronic myeloid leukemia. Sci Rep. 2015;5:12460.

91. Peng Y, Croce CM. The role of MicroRNAs in human cancer. Signal Transduct Target Ther. 2016;1:15004.

92. Carden T, Singh B, Mooga V, Bajpai P, Singh KK. Epigenetic modification of miR-663 controls mitochondria-to-nucleus retrograde signaling and tumor progression. J Biol Chem. 2017;292:20694-706.

93. Zhang Y, Xu X, Zhang M, Wang X, Bai X, Li H, Kan L, Zhou Y, Niu H, He P. MicroRNA-663a is downregulated in non-small cell lung cancer and inhibits proliferation and invasion by targeting JunD. BMC Cancer. 2016:16:315.

94. Bader AG. miR-34-a microRNA replacement therapy is headed to the clinic. Front Genet. 2012;3:120.

95. Wiggins JF, Ruffino L, Kelnar K, Omotola M, Patrawala L, Brown D, Bader AG. Development of a lung cancer therapeutic based on the tumor suppressor microRNA-34. Cancer Res. 2010;70:5923-30.

96. Slabáková E, Culig Z, Remšík J, Souček K. Alternative mechanisms of miR-34a regulation in cancer. Cell Death Dis. 2017:8:e3100.

97. Xia X, Yang B, Zhai X, Liu X, Shen K, Wu Z, Cai J. Prognostic role of microRNA-21 in colorectal cancer: a meta-analysis. PLoS ONE. 2013;8:e80426.

98. Kjaer-Frifeldt S, Hansen T, Nielsen B, Joergensen S, Lindebjerg J, Soerensen F, dePont Christensen R, Jakobsen A. The prognostic importance of miR-21 in stage II colon cancer: a population-based study. Br J Cancer. 2012:107:1169.

99. Kang WK, Lee JK, Oh ST, Lee SH, Jung CK. Stromal expression of miR-21 in T3-4a colorectal cancer is an independent predictor of early tumor relapse. BMC Gastroenterol. 2015;15:2.

100. Zhang J-X, Song W, Chen Z-H, Wei J-H, Liao Y-J, Lei J, Hu M, Chen G-Z, Liao B, Lu J. Prognostic and predictive value of a microRNA signature 
in stage II colon cancer: a microRNA expression analysis. Lancet Oncol. 2013;14:1295-306.

101. Nielsen BS, Jørgensen S, Fog JU, Søkilde R, Christensen IJ, Hansen U, Brünner N, Baker A, Møller S, Nielsen HJ. High levels of microRNA-21 in the stroma of colorectal cancers predict short disease-free survival in stage II colon cancer patients. Clin Exp Metastasis. 2011;28:27-38.

102. Lee KS, Nam SK, Koh J, Kim D-W, Kang S-B, Choe G, Kim WH, Lee HS. Stromal expression of microRNA-21 in advanced colorectal cancer patients with distant metastases. J Pathol Transl Med. 2016:50:270

103. Zuo Q, Cao L, Yu T, Gong L, Wang L, Zhao Y, Xiao B, Zou Q. MicroRNA-22 inhibits tumor growth and metastasis in gastric cancer by directly targeting MMP14 and Snail. Cell Death Dis. 2015;6:e2000.

104. Song SJ, Pandolfi PP. miR-22 in tumorigenesis. Cell Cycle. 2014;13:11-2.

105. Yang F, Hu Y, Liu H-X, Wan Y-JY. MiR-22-silenced cyclin A expression in colon and liver cancer cells is regulated by bile acid receptor. J Biol Chem. 2015;290:6507-15.

106. Wan W-N, Zhang Y-Q, Wang X-M, Liu Y-J, Zhang Y-X, Que Y-H, Zhao W-J, Li P. Down-regulated miR-22 as predictive biomarkers for prognosis of epithelial ovarian cancer. Diagn Pathol. 2014;9:178.

107. James AB, Fadaka AO, Magbagbeola OA, Oturu A, Kolawole OO, Ogunjimi A, Oshodi T, Habeebu M, Onawoga FO, Ajogbeje EO. Haematological and miRNAs (let-7g, miR-21, miR-141) expression modulation profile in serum samples of Human prostate cancer. FASEB J. 2017;31:757.12.

108. Li P, Xu Q, Zhang D, Li X, Han L, Lei J, Duan W, Ma Q, Wu Z, Wang Z. Upregulated miR-106a plays an oncogenic role in pancreatic cancer. FEBS Lett. 2014;588:705-12.

109. Yang G, Zhang R, Chen X, Mu Y, Ai J, Shi C, Liu Y, Shi C, Sun L, Rainov NG. MiR-106a inhibits glioma cell growth by targeting E2F1 independent of p53 status. J Mol Med. 1037;2011:89.

110. Wang Z, Liu M, Zhu H, Zhang W, He S, Hu C, Quan L, Bai J, Xu N. miR106a is frequently upregulated in gastric cancer and inhibits the extrinsic apoptotic pathway by targeting FAS. Mol Carcinog. 2013;52:634-46.

111. Syed DN, Suh Y, Afaq F, Mukhtar H. Dietary agents for chemoprevention of prostate cancer. Cancer Lett. 2008;265:167-76.

112. Tili E, Michaille J-J, Alder H, Volinia S, Delmas D, Latruffe N, Croce CM. Resveratrol modulates the levels of microRNAs targeting genes encoding tumor-suppressors and effectors of TGF $\beta$ signaling pathway in SW480 cells. Biochem Pharmacol. 2010:80:2057-65.

113. Yoo YA, Kang MH, Kim JS, Oh SC. Sonic hedgehog signaling promotes motility and invasiveness of gastric cancer cells through TGF- $\beta$ mediated activation of the ALK5-Smad 3 pathway. Carcinogenesis. 2008:29:480-90.

114. Tili E, Michaille J-J, Adair B, Alder H, Limagne E, Taccioli C, Ferracin M, Delmas D, Latruffe N, Croce CM. Resveratrol decreases the levels of miR155 by upregulating miR-663, a microRNA targeting JunB and JunD. Carcinogenesis. 2010;31:1561-6.

115. Kumazaki M, Noguchi S, Yasui Y, Iwasaki J, Shinohara H, Yamada N, Akao Y. Anti-cancer effects of naturally occurring compounds through modulation of signal transduction and miRNA expression in human colon cancer cells. J Nutr Biochem. 2013;24:1849-58.

116. Gonçalves P, Martel F. Butyrate and colorectal cancer: the role of butyrate transport. Curr Drug Metab. 2013;14:994-1008.

117. Sengupta S, Muir JG, Gibson PR. Does butyrate protect from colorectal cancer? J Gastroenterol Hepatol. 2006;21:209-18.

118. Fung KY, Cosgrove L, Lockett T, Head R, Topping DL. A review of the potential mechanisms for the lowering of colorectal oncogenesis by butyrate. Br J Nutr. 2012;108:820-31.

119. Hu S, Dong TS, Dalal SR, Wu F, Bissonnette M, Kwon JH, Chang EB. The microbe-derived short chain fatty acid butyrate targets miRNAdependent p21 gene expression in human colon cancer. PLOS ONE. 2011;6:e16221.

120. Hu S, Liu L, Chang EB, Wang J-Y, Raufman J-P. Butyrate inhibits proproliferative miR-92a by diminishing c-Myc-induced miR-17-92a cluster transcription in human colon cancer cells. Mol Cancer. 2015;14:180.

121. Humphreys KJ, Cobiac L, Le Leu RK, Van der Hoek MB, Michael MZ. Histone deacetylase inhibition in colorectal cancer cells reveals competing roles for members of the oncogenic miR-17-92 cluster. Mol Carcinog. 2013;52:459-74

122. Williams $C D$, Whitley $B M$, Hoyo C, Grant DJ, Iraggi JD, Newman KA, Gerber L, Taylor LA, McKeever MG, Freedland SJ. A high ratio of dietary $\mathrm{n}-6 / \mathrm{n}-3$ polyunsaturated fatty acids is associated with increased risk of prostate cancer. Nutr Res. 2011;31:1-8.

123. Gopinath B, Buyken AE, Flood VM, Empson M, Rochtchina E, Mitchell P. Consumption of polyunsaturated fatty acids, fish, and nuts and risk of inflammatory disease mortality. Am J Clin Nutr. 2011;93:1073-9.

124. Davidson LA, Wang N, Shah MS, Lupton JR, Ivanov I, Chapkin RS. n-3 Polyunsaturated fatty acids modulate carcinogen-directed non-coding microRNA signatures in rat colon. Carcinogenesis. 2009;30:2077-84.

125. Mandal CC, Ghosh-Choudhury T, Dey N, Choudhury GG, GhoshChoudhury N. miR-21 is targeted by omega-3 polyunsaturated fatty acid to regulate breast tumor CSF-1 expression. Carcinogenesis. 2012;33:1897-908.

126. Mudduluru G, George-William JN, Muppala S, Asangani IA, Kumarswamy R, Nelson LD, Allgayer H. Curcumin regulates miR-21 expression and inhibits invasion and metastasis in colorectal cancer. Biosci Rep. 2011;31:185-97.

127. Bao B, Ali S, Kong D, Sarkar SH, Wang Z, Banerjee S, Aboukameel A, Padhye S, Philip PA, Sarkar FH. Anti-tumor activity of a novel compoundCDF is mediated by regulating miR-21, miR-200, and PTEN in pancreatic cancer. PLOS ONE. 2011:6:e17850.

128. Sun M, Estrov Z, Ji Y, Coombes KR, Harris DH, Kurzrock R. Curcumin (diferuloylmethane) alters the expression profiles of microRNAs in human pancreatic cancer cells. Mol Cancer Ther. 2008;7:464-73.

129. Ali S, Ahmad A, Banerjee S, Padhye S, Dominiak K, Schaffert JM, Wang Z, Philip PA, Sarkar FH. Gemcitabine sensitivity can be induced in pancreatic cancer cells through modulation of miR-200 and miR-21 expression by curcumin or its analogue CDF. Cancer Res. 2010;70:3606-17.

130. Zhang J, Zhang T, Ti X, Shi J, Wu C, Ren X, Yin H. Curcumin promotes apoptosis in A549/DDP multidrug-resistant human lung adenocarcinoma cells through an miRNA signaling pathway. Biochem Biophys Res Commun. 2010:399:1-6.

131. Parasramka MA, Ho E, Williams DE, Dashwood RH. MicroRNAs, diet, and cancer: new mechanistic insights on the epigenetic actions of phytochemicals. Mol Carcinog. 2012;51:213-30.

132. Saini S, Majid S, Dahiya R. Diet, microRNAs and prostate cancer. Pharm Res. 2010;27:1014-26.

133. Gandini S, Boniol M, Haukka J, Byrnes G, Cox B, Sneyd MJ, Mullie P, Autier P. Meta-analysis of observational studies of serum 25-hydroxyvitamin D levels and colorectal, breast and prostate cancer and colorectal adenoma. Int J Cancer. 2011;128:1414-24.

134. Alvarez-Díaz S, Valle N, Ferrer-Mayorga G, Lombardía L, Herrera M, Domínguez O, Segura MF, Bonilla F, Hernando E, Muñoz A. MicroRNA-22 is induced by vitamin $D$ and contributes to its antiproliferative, antimigratory and gene regulatory effects in colon cancer cells. Hum Mol Genet. 2012;21:2157-65.

135. Padi SK, Zhang Q, Rustum YM, Morrison C, Guo B. MicroRNA-627 mediates the epigenetic mechanisms of vitamin $D$ to suppress proliferation of human colorectal cancer cells and growth of xenograft tumors in mice. Gastroenterology. 2013;145:437-46.

136. Tinggi U. Selenium: its role as antioxidant in human health. Environ Health Prev Med. 2008:13:102-8.

137. Sarveswaran S, Liroff J, Zhou Z, Nikitin AY, Ghosh J. Selenite triggers rapid transcriptional activation of p53, and p53-mediated apoptosis in prostate cancer cells: implication for the treatment of early-stage prostate cancer. Int J Oncol. 2010;36:1419-28.

138. Nian H, Bisson WH, Dashwood W-M, Pinto JT, Dashwood RH. a-Keto acid metabolites of organoselenium compounds inhibit histone deacetylase activity in human colon cancer cells. Carcinogenesis. 2009;30:1416-23.

139. Li Y, VandenBoom TG, Wang Z, Kong D, Ali S, Philip PA, Sarkar FH. miR-146a suppresses invasion of pancreatic cancer cells. Cancer Res. 2010;70:1486-95.

140. Majid S, Dar AA, Saini S, Chen Y, Shahryari V, Liu J, Zaman MS, Hirata H, Yamamura S, Ueno K. Regulation of minichromosome maintenance gene family by microRNA-1296 and genistein in prostate cancer. Cancer Res. 2010;70:2809-18.

141. Parker L, Taylor D, Kesterson J, Metzinger D, Gercel-Taylor C. Modulation of microRNA associated with ovarian cancer cells by genistein. Eur J Gynaecol Oncol. 2009;30:616-21.

142. Edvardsson K, Nguyen-Vu T, Kalasekar SM, Pontén F, Gustafsson $J$-Å, Williams C. Estrogen receptor $\beta$ expression induces changes in 
the microRNA pool in human colon cancer cells. Carcinogenesis. 2013;34:1431-41.

143. Okuda T, Yoshida T, Hatano T. Ellagitannins as active constituents of medicinal plants. Planta Med. 1989;55:117-22.

144. Wen XY, Wu SY, Li ZQ, Liu ZQ, Zhang JJ, Wang GF, Jiang ZH, Wu SG. Ellagitannin (BJA3121), an anti-proliferative natural polyphenol compound, can regulate the expression of MiRNAs in HepG2 cancer cells. Phytother Res. 2009;23:778-84.

145. Mercken EM, Carboneau BA, Krzysik-Walker SM, de Cabo R. Of mice and men: the benefits of caloric restriction, exercise, and mimetics. Ageing Res Rev. 2012;11:390-8.

146. Steinbach G, Heymsfield S, Olansen NE, Tighe A, Holt PR. Effect of caloric restriction on colonic proliferation in obese persons: implications for colon cancer prevention. Cancer Res. 1994;54:1194-7.

147. Kritchevsky D. Colorectal cancer: the role of dietary fat and caloric restriction. Mutat Res Fundam Mol Mech Mutagen. 1993;290:63-70.

148. Fontana L, Mitchell SE, Wang B, Tosti V, van Vliet T, Veronese N, Bertozzi B, Early DS, Maissan P, Speakman JR. The effects of graded caloric restriction: XII. Comparison of mouse to human impact on cellular senescence in the colon. Aging Cell. 2018;17:e12746.

149. Hayflick $L$. The limited in vitro lifetime of human diploid cell strains. Exp Cell Res. 1965;37:614-36.

150. Mooi W, Peeper D. Oncogene-induced cell senescence-halting on the road to cancer. N Engl J Med. 2006;355:1037-46.

151. Ghosh K, Capell BC. The senescence-associated secretory phenotype: critical effector in skin cancer and aging. J Invest Dermatol. 2016;136:2133-9.

152. Rao SG, Jackson JG. SASP: tumor suppressor or promoter? Yes! Trends Cancer. 2016:2:676-87.
153. Vaughan S, Jat PS. Deciphering the role of nuclear factor-kB in cellular senescence. Aging (Albany NY). 2011;3:913.

154. Karin M. Nuclear factor-KB in cancer development and progression. Nature. 2006;441:431.

155. Hursting SD, Dunlap SM, Ford NA, Hursting MJ, Lashinger LM. Calorie restriction and cancer prevention: a mechanistic perspective. Cancer Metab. 2013;1:10

156. Stattin P, Palmqvist R, Söderberg S, Biessy C, Ardnor B, Hallmans G, Kaaks $\mathrm{R}$, Olsson T. Plasma leptin and colorectal cancer risk: a prospective study in Northern Sweden. Oncol Rep. 2003;10:2015-21.

157. Harvey AE, Lashinger LM, Otto G, Nunez NP, Hursting SD. Decreased systemic IGF-1 in response to calorie restriction modulates murine tumor cell growth, nuclear factor-kB activation, and inflammationrelated gene expression. Mol Carcinog. 2013;52:997-1006.

158. Harvey AE, Lashinger LM, Hays D, Harrison LM, Lewis K, Fischer SM, Hursting SD. Calorie restriction decreases murine and human pancreatic tumor cell growth, nuclear factor-kB activation, and inflammationrelated gene expression in an insulin-like growth factor-1—dependent manner. PLoS ONE. 2014;9:e94151.

159. Jin L, Lim M, Zhao S, Sano Y, Simone BA, Savage JE, Wickstrom E, Camphausen K, Pestell RG, Simone NL. The metastatic potential of triple-negative breast cancer is decreased via caloric restrictionmediated reduction of the miR-17 92 cluster. Breast Cancer Res Treat. 2014:146:41-50.

160. Devlin KL, Sanford T, Harrison LM, LeBourgeois P, Lashinger LM, Mambo E, Hursting SD. Stage-specific MicroRNAs and their role in the anticancer effects of calorie restriction in a rat model of ER-positive luminal breast cancer. PLoS ONE. 2016;11:e0159686.
Ready to submit your research? Choose BMC and benefit from:

- fast, convenient online submission

- thorough peer review by experienced researchers in your field

- rapid publication on acceptance

- support for research data, including large and complex data types

- gold Open Access which fosters wider collaboration and increased citations

- maximum visibility for your research: over 100M website views per year

At BMC, research is always in progress.

Learn more biomedcentral.com/submissions 